\title{
Lectotypification of Hyphaene dichotoma and Arenga wightii (Arecaceae)
}

\author{
Lawand, P.R. ${ }^{1}$, S.S. Kambale ${ }^{2}$, V.B. Shimpale ${ }^{1 *}$ and S.R. Yadav ${ }^{3}$ \\ 'Department of Botany, The New College, Kolhapur, Maharashtra - 416 012, India. \\ 2Department of Botany, MVP Samaj's Arts, Commerce and Science College, Tryambakeshwar, Nashik, \\ Maharashtra - 422 212, India. \\ ${ }^{3}$ Angiosperm Taxonomy Laboratory, Department of Botany, Shivaji University, Kolhapur, \\ Maharashtra - 416 004, India. \\ *E-mail: vshimpale@gmail.com
}

\begin{abstract}
The names Hyphaene dichotoma and Arenga wightii are typified. Citation anomaly in $H$. dichotoma has been clarified.
\end{abstract}

Keywords: Arecaceae, Arenga wightii, epitype, Hyphaene dichotoma, lectotype

\section{Introduction}

Arecaceae, a distinct component of tropical and subtropical habitat comprises c. 2400 species in 187 (www.theplantlist.org) genera. The genus Hyphaene Gaertn. possess peculiar dichotomously branching habit and is represented by eight species in the world (Dransfield et al., 2008) distributed throughout Africa, Madagascar and India. Hyphaene dichotoma (J.White Dubl. ex Nimmo) Furtado is endemic to India.

Arenga Labill. is a South east Asian genus comprising 25 species. In India, the genus is represented by three species viz., A. wightii Griff., A. westerhoutii Griff. and A. pinnata (Wurmb) Merr., of which, A. wightii is threatened and endemic to India (IUCN, 2017). As part of taxonomic studies in Indian palms Hyphaene dichotoma (J. White Dubl. ex Nimmo) Furtado and Arenga wightii Griff. were found to lack proper typification. Hence, lectotypes are selected for these names conforming to the latest botanical code and an epitype $H$. dichotoma is selected following Art. 9.3 and Art. 9.9 of Shenzhen Code (Turland et al., 2018) respectively.

Hyphaene dichotoma (J.White Dubl. ex Nimmo) Furtado, Gard. Bull. Singapore 25: 301. 1970.

Borassus dichotomus J.White Dubl. ex Nimmo in J. Graham, Cat. Pl. Bombay 226. 1839.

Lectotype (designated here): INDIA, Andhra Pradesh, Masulipatam, Palmyra Tree Sketch No. 1 Madras J. Lit. Sci. 1(1): 12. 1833.

Fig. 2.
Epitype (designated here): INDIA, Diu, Nagoa beach, 28.1.2014, P.R.Lawand PRL001 (SUK!). Fig. 3.

Notes: H. dichotoma was originally described by White (1839) under the genus Borassus (as B.

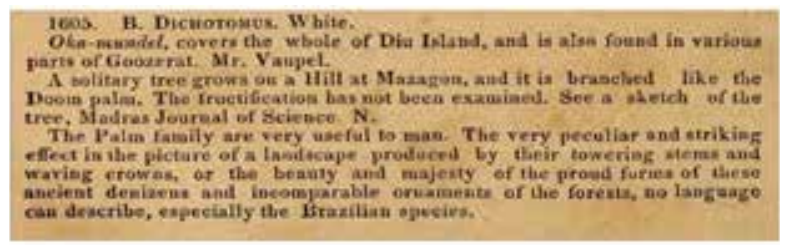

Fig. 1. Protologue of Borassus dichotomus J. White Dubl. ex Nimmo (Image reproduced from http://www. biodiversitylibrary.org).



Fig. 2. Lectotype of Hyphaene dichotoma (J.White Dubl. ex Nimmo) Furtado, One of three illustrations of Bowler's Remarkable Palmyra Tree (Image reproduced from http:// www.books.google.co.in). 
dichotomus) in Graham's "Catalogue of Plants Growing in Bombay and its vicinity". While describing the species, White did not mention any specimen however; he mentioned a sketch of this palm in Madras Journal of Literature without precise year and volume number. Details of the sketches have been mentioned by Martius (1850). The sketches were already catalogued prior to publication of this species under the title "Description and Drawings of some Remarkable Palmyra Tree in the Northern Circars" in Madras Journal of Literature and Science by Bowler (1833).

Later, Furtado (1970) transferred Borassus dichotomus to Hyphaene and made new combination as Hyphaene dichotoma. Because of the unavailability of any known specimen, the only existing material the sketch 'No. 1' published by Bowler should be considered as an original material which has been chosen here as a lectotype for $H$. dichotoma according to article No. 9.3 of Shenzhen code (Turland et al., 2018).

The selected lectotype depicts only the habit which is inadequate or ambiguous for precise identification of the species. Hence, a flowering specimen collected by the first author from one of the type localities, Diu Island in Gujarat, is

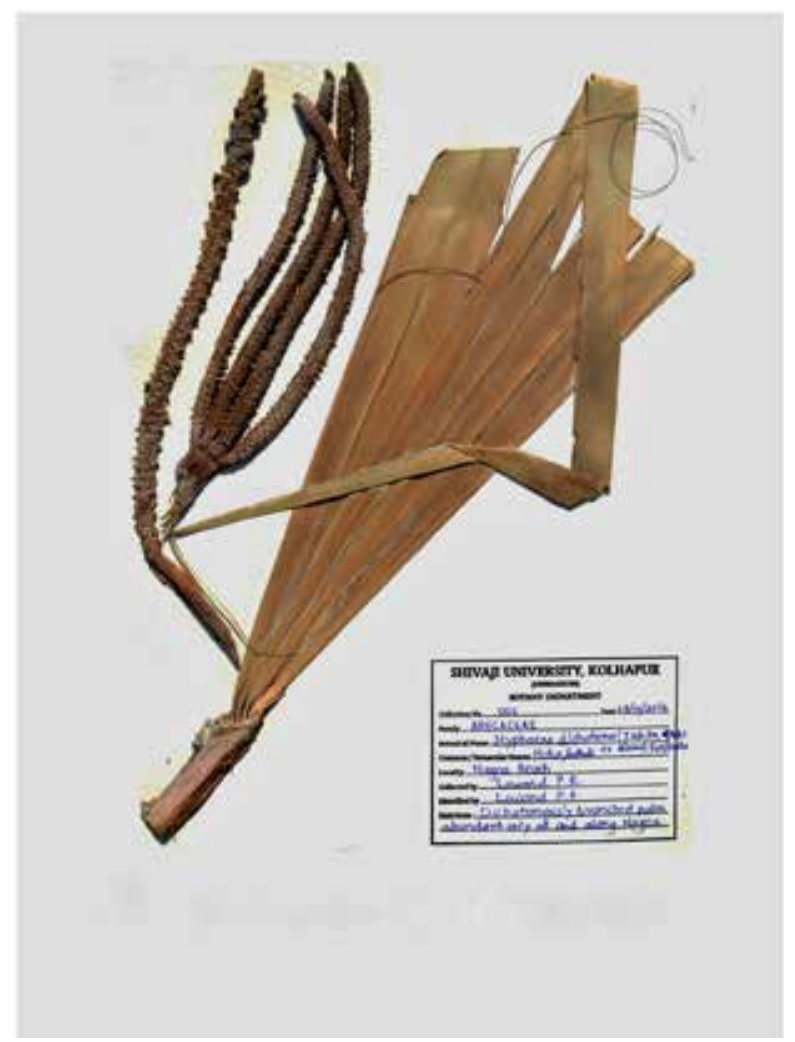

Fig. 3. Epitype of Hyphaene dichotoma (J.White Dubl. ex Nimmo) Furtado (P.R. Lawand PRL 001, SUK). designated here as an epitype following Art. 9.9 of Shenzhen Code (Turland et al., 2018).

\section{Discussion on authority citation}

Ever since its publication, the name Borassus dichotomus was ascribed only to John White (Chaphekar et al., 2007, Ravikiran \& Das, 2010, www.theplantlist.org, www.tropicos.org). However, the information given in the protologue was provided by Vaupel and Nimmo (indicated by ' $N$ ' after the description.). Moreover, Graham's "Catalogue of Plants Growing in Bombay and its vicinity" was completed and published posthumously by Nimmo. Since the important diagnostic description in the protologue was provided by Nimmo, correct author citation for this binomial should be written as 'Hyphaene dichotoma (J.White Dubl. ex Nimmo) Furtado (=Borassus dichotomus J.White Dubl. ex Nimmo)'.

Arenga wightii Griff., Calcutta J. Nat. Hist. 5: 475. 1845.

Lectotype (designated here): INDIA, Tamil Nadu, Coimbatore, R. Wight s.n. (BR0000013237035 image!).

Fig. 4.

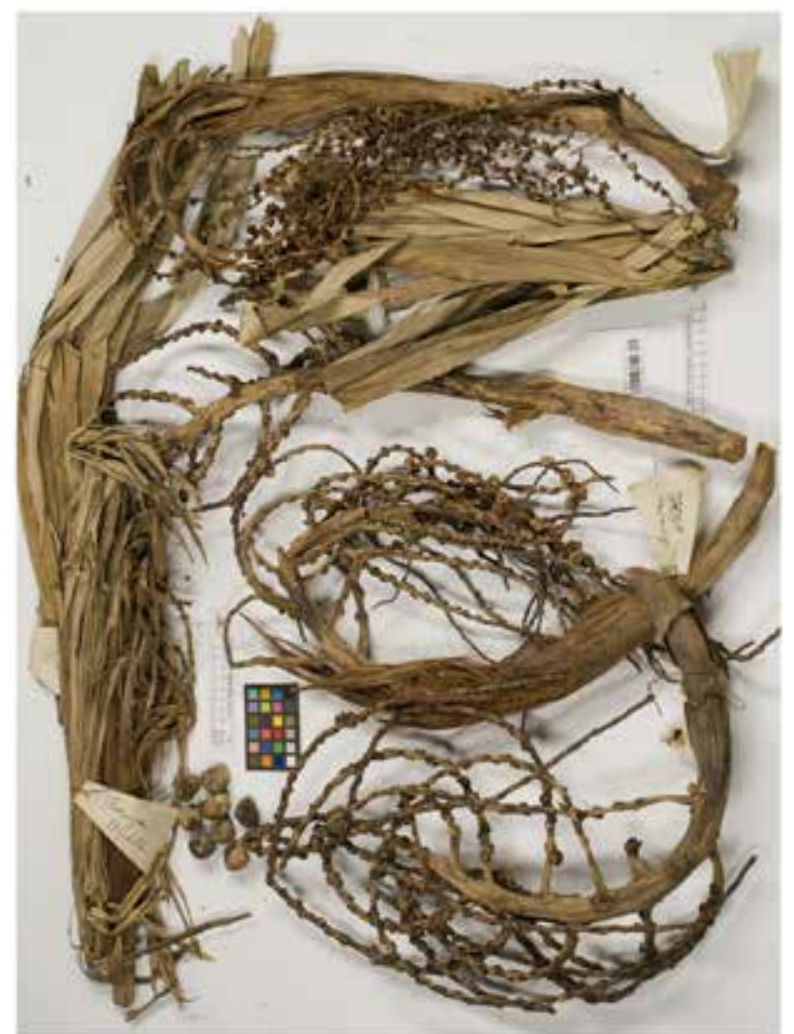

Fig. 4. Lectotype of Arenga wightii Griff. (BR0000013237035). 
Griffith (1845) described Arenga wightii based on specimens received from Robert Wight. Whatever specimens he received were 'sine numero' but in protologue he mentioned all the details of those specimens. Von Martius then acquired many of Griffith's material and Martius' widow sold a lot of specimens to the Brussels Herbarium (BR), Botanic Garden Meise, Belgium (John Dransfield., Pers. comm., 14.01.2014). Authors could trace two specimens at 'BR' viz., BR0000013237035 and BR0000006727802. The material on specimen BR0000013237035 correctly matches to the details provided by Griffith. Hence this specimen is selected here as lectotype following Art. 9.3 of Shenzhen code (Turland et al., 2018). The specimen BR0000006727802 was annotated as 'Type or Isotype' by H.E. Moore, Jr. but such labels cannot be considered as an effective typification of the species. This specimen is one of the communicated samples from Robert Wight to Griffith, therefore, should be treated as isolectotype.

\section{Acknowledgements}

Authors are thankful to Quentin Groom, Research Assistant, Botanic Garden Meise for providing images of Arenga wightii and permission to use it in a publication. Authors express their sincere thanks to John Dransfield, Royal Botanic Gardens, Kew and Dr. K. N. Gandhi, Senior Nomenclatural Registrar, Harvard University Herbaria and Libraries for their expert suggestions and kind help. Authors also thank Forest Dept., Govt. of Maharashtra for financial assistance. PRL thank Council of Scientific and Industrial Research (CSIR) for financial aid (File No. 08/631(0001)/2015-EMR-I).

\section{Literature Cited}

Beccari, O. 1908. Le Palmae "Dum" od "Hyphaene": e piu specialmente quelle dell' Africa Italiana. Agric. Colon. Anno. 2, fasc. Firenze. 3: 137-183.

Bowler, W.S. 1833. Descriptions and drawings of some remarkable Palmyra trees in the Northern Circars. Madras J. Lit. Sci. 1(1): 13.

Chaphekar, S., Lattoo, C. \& D.M. Karnik 2007. Sen Trees of Mumbai. Centre for extra mural studies, University of Mumbai.
Dransfield, J., Uhl, N.W., Asmussen, C.B., Baker, W.J., Harley, M.M. \& C.E. Lewis 2008. Genera Palmarum: Evolution and classification of the Palms (Ed. 2). Royal Botanic Gardens, Kew.

Furtado, C.X. 1970. Asian species of Hyphaene. Gard. Bull., Singapore 25: 301-303.

Griffith, W. 1845. The Palms of British East India. Calcutta J. Nat. Hist. 5: 475-477.

IUCN 2017. The IUCN Red List of Threatened Species. Version 2017-3. <http://www. iucnredlist.org>. Downloaded on 04.07.2018.

Martius, K.F.P. von 1850. Historia Naturalis Palmarum Vol. 3. T.O. Weigel, Leipzig. p. 318.

Ravi Kiran, A. \& K.M.J.M., Das 2010. Hyphaene dichotoma L. (Gingerbread Palm) Arecaceae- a rare, sacred and exotic palm tree in Andhra Pradesh. Natl. Acad. Sci. Lett. 33(3 \& 4): 59-62.

The Plant List: http://www. theplantlist.org/

Tropicos: http://www.tropicos.org/Home.aspx

Turland, N.J., Wiersema, J.H, Barrie, F.R., Greuter, W., Hawksworth, D.L., Hereunder, P.S., Knapp, S., Kusber, W.H., Li, D.Z., Marhold, K., May, T.W., McNeill, J., Monro, A. M., Prado, J., Price, M.J. \& G.F. Smith 2018. International code of Nomenclature for algae, fungi and plants (Shenzhen code). Regnum Vegetabile 159. Koeltz Botanical Books, Glashütten. DOI https://doi.org/10.12705/Code.2018

White (of Dublin), J. 1839. Borassus dichotomus. In: Graham, J. (Ed.) A Catalogue of the plants growing in Bombay and its vicinity. The Government Press, Bombay.

Receiced: 11.11.2016

Revised and Accepted: 23.06.2018 